\title{
EML4/ALK Fusion Gene Variant 1
}

National Cancer Institute

\section{Source}

National Cancer Institute. EML4IALK Fusion Gene Variant 1. NCI Thesaurus. Code C99725.

A fusion gene ( $3.9 \mathrm{~kb})$ that results from a chromosomal inversion inv(2)(p21p23) which fuses exon 13 of the EML4 gene with exons 20-29 of the ALK gene. This fusion is associated with non-small cell lung cancer. 